\title{
Model Tata Kelola dan Perilaku Bisnis Stand/Booth Container di Provinsi Jambi
}

\author{
Tona Aurora Lubis ${ }^{1}$, Syahmardi Yacob², Firmansyah ${ }^{3}$ \\ Fakultas Ekonomi dan Bisnis, Universitas Jambi ${ }^{1,2,3}$ \\ *correspondence e-mail: tonalubis@unja.ac.id
}

\begin{abstract}
Street food business phenomenon gives a new touch in the culinary industry of Jambi Province because of the unique way of selling that does not use stalls or tents, but uses a knock down cart in the form of a box shaped like a container, so it is known as stand /Booth Container. The ultimate goal of this research is to formulate a model of governance and business behavior of stand/booth containers in Jambi Province. This study used mixed methods (qualitative and quantitative methods) using the type of Sequal Exploratory Design. The result conluded that the business behavior of food outlets/containers in Jambi Province which is reflected by efficiency, innovation, creativity, and creativity affects business performance which is reflected by capital growth, profit growth, and sales growth. In contrast, governance as reflected by modern, partnership and systematic does not affect business performance which is reflected by capital growth, profit growth and sales growth.
\end{abstract}

Keywords: Food Booth/Container; Business Performance; Business Conduct; Governance; Business Performance

\section{Pendahuluan}

Saat ini sektor pangan merupakan salah satu sektor yang menjadi pilihan begitu banyak kaum wirausaha untuk digeluti. Seakan tidak ada habisnya, sektor ini terus berkembang dari masa ke masa. Selain menjadi kebutuhan dasar, sektor pangan juga telah menjadi gaya hidup baru di tengah masyarakat. Pangan berubah menjadi sebuah industi kuliner yang mampu memberi sentuhan baru yang lebih dari sekadar cita rasa, namun juga sarana untuk bersosialisasi dan beraktualisasi. (Danielsson 2020) menambahkan bahwa hal itu dikarenakan industri kuliner yang terus berkembang tidak hanya menjual makanan dan minuman sebagai core bisnisnya namun juga telah memberikan ruang bagi para konsumen untuk dapat bertemu dan berkumpul bersama komunitasnya. Menurut data Kementrian Perindustrian (Kemenperin) RI mencatat bahwa sektor pangan/makanan dan minuman berhasil menyumbang Produk Domestik Bruto (PDB) Nasional sebesar 6, 43\% pada tahun 2018. Capaian tersebut telah naik 0,23\% dari angka 6, $21 \%$ pada tahun 2017. Angka ini diproyeksikan akan terus berkembang sejalan dengan adanya peningkatan fokus pemerintah pada sektor industri kreatif, yang salah satu subsektornya ialah kuliner.

Demikian juga halnya di Provinsi Jambi, mengalami hal serupa mengenai perkembangan industri kulinernya. Namun dalam perjalanannya, industri kuliner di Provinsi Jambi dalam beberapa tahun terakahir memberikan nuansa tersendiri yang cukup khas jika dibandingkan dengan tahun-tahun sebelumnya. Bisnis makanan di pinggir jalan atau biasa dikenal sebagai street food business mulai menjamur. Menurut World Health Organization (WHO), Street food atau Jajanan Pinggir Jalan merupakan sebuah istilah yang digunakan untuk menjelaskan 'makanan dan minuman siap saji yang disiapkan dan/atau dijual oleh pedagang kaki lima dan pedagang asongan terutama di jalan-jalan dan tempat lain yang sejenis' dalam (Abrahale dan Sousa 2018). Adanya fenonema street food inipun memberikan kontribusi yang luar biasa terhadap banyak pihak, misalnya kemudahan bagi masyarakat lokal dalam memperoleh makanan hingga menaikkan antusiasme turis/ wisatawan mancanegara (Alfiero, Giudice, dan Bonadonna 2017). Harga yang relatif terjangkau, mudah ditemui, kecepatan pelayanan, hingga keautentikan rasa menjadi beberapa alasan street food menjadi pilihan masyarakat (Privitera dan Nesci 2015), terutama dinegara negara berkembang dengan tingkat pendapatan masyarakat menengah (Chavez et al. 2021).

Gaya hidup modern, perubahan struktur keluarga, waktu persiapan makanan yang terbatas, serta alasan sosial ekonomi lainnya juga menyebabkan perubahan yang cukup signifikan dalam atribut pemilihan makanan dan pola konsumsi konsumen. Selanjutnya, perubahan permintaan konsumen dan preferensi untuk lebih memilih makan di luar memotivasi konsumen untuk mengunjungi gerai street food (Gupta, Khanna, dan Gupta 2018). Fenomena street food ini terus berkembang tidak hanya dalam hal ragam dan cita rasa makanan namun juga dalam hal tempat menyajikan makanan. Perkembangannya tidak hanya sekadar menggunakan warung atau tenda, namun telah menggunakan gerobak knock down yang berbentuk box yang berbentuk seperti Container, sehingga dikenal dengan istilah stand/ Booth Container (Chaisena, Thiengkamol, dan Thiengkamol 2013). Food Stand/ Booth container biasanya banyak ditemui di alun-alun, dekat rumah, pusat transportasi, dan tempat kerja (Chavez et al. 2021).

Street food business sebagai entitas bisnis memiliki keunikan berbeda seperti pada display yang digunakan. Keunikan ini memungkinkan konsumen untuk melihat secara langsung dapur dari bisnis, yakni proses persiapan makaanan ataupun minumannya hingga menyajikannya ke pembeli. Namun sayangnya, menurut (Alves da Silva et al. 2014; Morano et al. 2018) proses persiapan dan penyajian yang kadang terlalu terbuka tersebut menyebabkan 
kurangnya higienitas yang ditawarkan. Sementara itu, pada sisi sumber daya manusia, membutuhkan sumber daya manusia yang handal baik sebagai karyawan maupun pemilik usaha. Kaum millenial mengambil peran dalam perkembangan bisnis stand/booth container di Provinsi Jambi. Adanya antusiasme ini perlu ditubuhkembangkan sebagai solusi alternatif pengembangan ekonomi kreatif di Provinsi Jambi. Oleh karena itu, penelitian ini menjadi penting dan menarik untuk meneliti tentang Model Tata Kelola dan Perilaku Bisnis Stand/ Booth Container di Provinsi Jambi.

\section{Hasil}

Berdasarkan hasil Output NVivo berupa concept map tata kelola dan perilaku bisnis dalam food truck, maka dapat disimpulkan bahwa variabel tata kelola terdiri dari 5 indikator yaitu: Kemandirian, Partnership, Modern, Emoney dan Sistematis. Kemudian variabel perilaku bisnis terdiri dari 7 indikator yaitu: Kesederhanaan, Keefektifan, Kreativitas, Praktis, Efisiensi , Inovatif dan Kekinian.

Sumber: data olahan

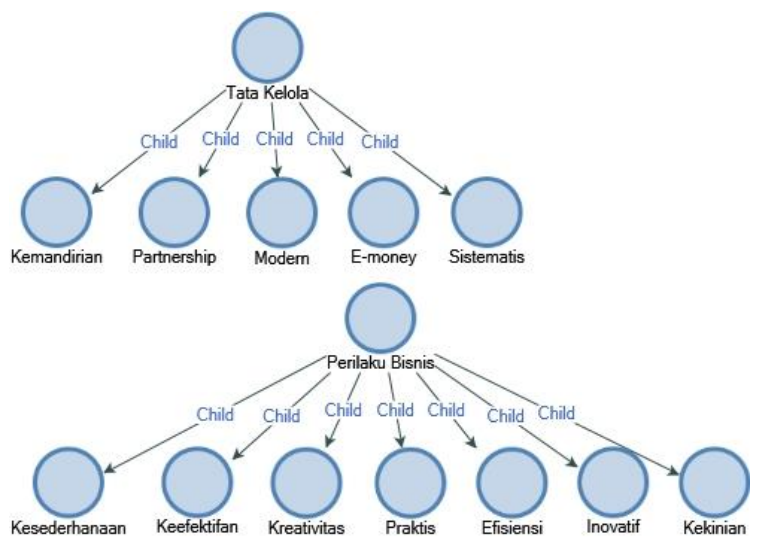

\section{Gambar 1.}

Concept Map

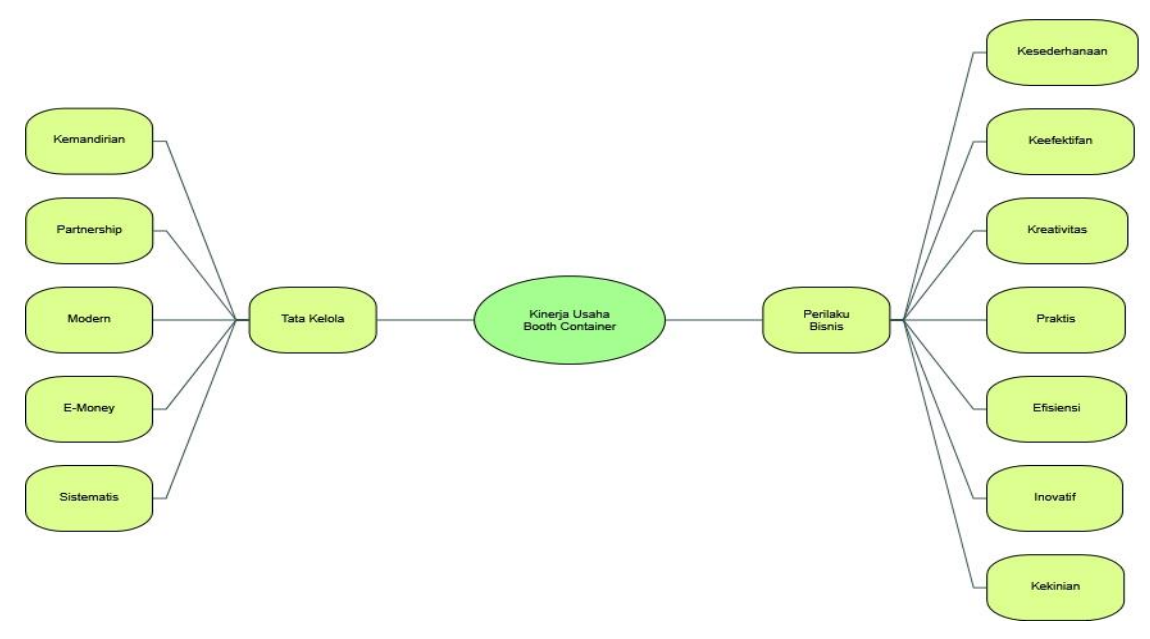

Sumber: data olahan

\section{Gambar 2.}

Mind Map

Gambar 2. menunjukkan pola variabel dan indikator dari penelitian ini. Selanjutnya, setelah melalui tahapan kualitatif dengan menemukan variabel dan indikator, maka tahapan selanjutnya memasuki tahapan kuantitatif. Berikut hasil output dari software smart PLS sebagai berikut: 


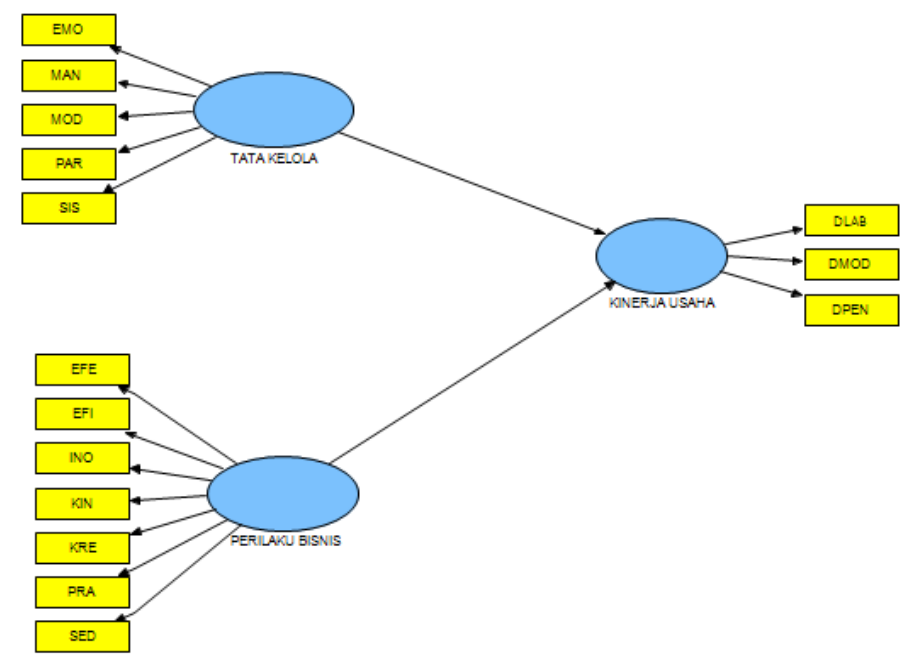

Sumber: data olahan

\section{Gambar 3.}

\section{Model Awal Penelitian}

Gambar 3. merupakan model awal penelitian yang menunjukkan pengaruh antar variabel. Perilaku bisnis terdiri dari 5 (lima) indikator, yaitu: e-money (E-money), kemandirian (MAN), modern (MOD), partnership (PAR), dan sistematis (SIS). Kemudian variabel perilaku bisnis terdiri dari 7 (tujuh) indikator keefektifan (EFE), efisiensi (Efi), Inovatif (INO), Kekinian (KIN), kreativitas (KRE), Praktis (PRA) dan Kesederhanaan (SED). Sementara itu, variabel kinerja usaha terdiri dari 3 (tiga) indikator yaitu pertumbuhan laba (DLAB), pertumbuhan Modal (DMOD) dan pertumbuhan penjualan (DPEN).

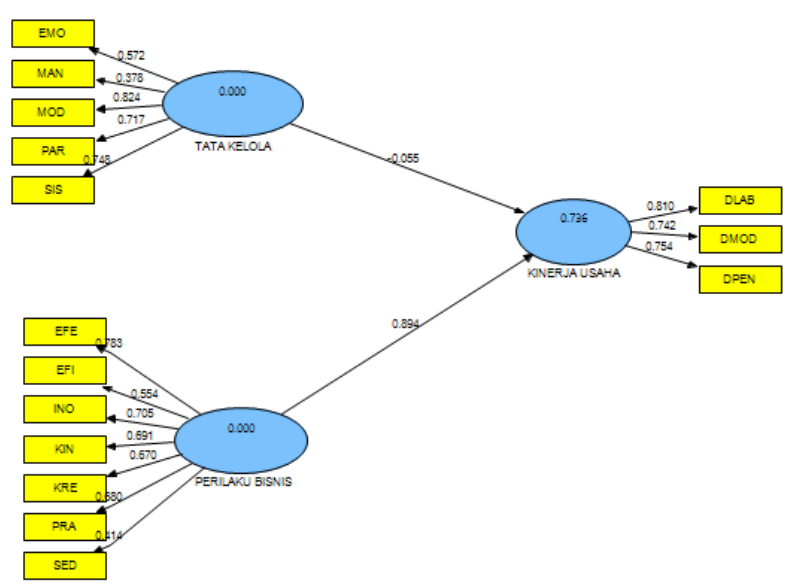

Sumber: data olahan

\section{Gambar 4. \\ Hasil Perhitungan Model Pertama}

Menurut Ghozali (2006) convergent validity dari model penelitian dapat dilihat dari korelasi antara score item/indikator dengan scorfe kontruknya. Indikator dianggap reliabel jika memiliki nilai korelasi diatas 0,70. Namun demikian pada riset tahap pengembangan skala loading 0,5 sampai 0,6 masih dapat diterima. Berdasarkan Gambar 4 . terlihat bahwa terdapat indikator yang mempunyai loading factor dibawah 0,6 yaitu indikator kemandirian pada variabel tata kelola dan indikator praktis serta efisiensi pada variabel perilaku bisnis. Indikator yang memiliki nilai loading factor dibawah 0,6 akan dikeluarkan dari model penelitian. Berikut model penelitian yang menampilkan model penelitian yang telah mengeluarkan indikator dengan loading factor dibawah 0,6 yang disajikan dalam Gambar 5 berikut: 


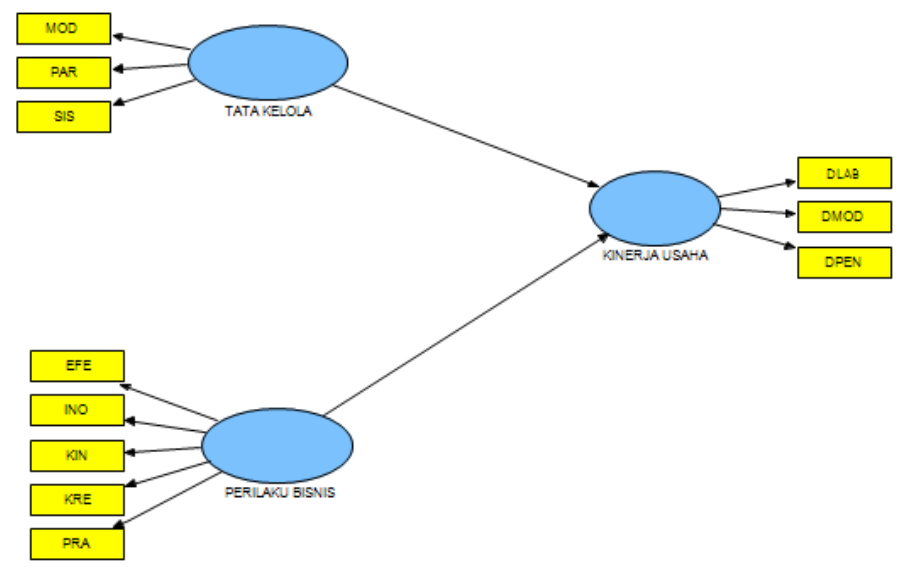

Sumber: data olahan

Gambar 5.

Model Kedua

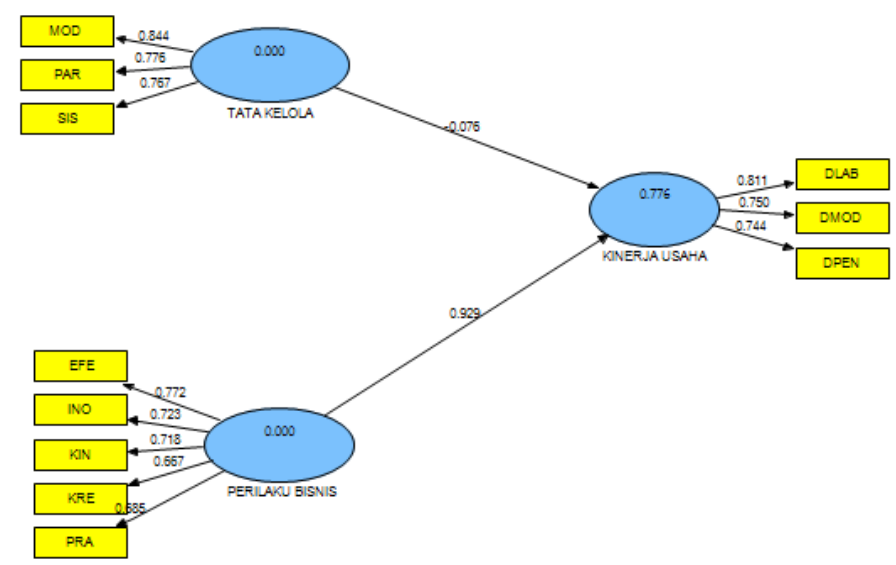

Sumber: data olahan

Gambar 6.

Hasil Perhitungan Model Kedua

Gambar 6. terlihat bahwa seluruh indikator dalam semua variabel telah memiliki loading factor diatas 0,6 . Hal ini menunjukkan bahwa inilah indikator-indikator yang merefleksikan masing-masing variabel dari penelitian ini. Pada variabel tata kelola terdiri dari 3 (tiga) indikator yaitu: modern (MOD), partnership (PAD) dan sistematis (SIS). Kemudian variabel perilaku bisnis terdiri dari 5 indikator yaitu : keefektifan (EFE), Inovatif (INO), Kekinian (KIN), kreativitas (KRE), dan Praktis (PRA). Sementara itu, variabel kinerja usaha terdiri dari 3 (tiga) indikator yaitu pertumbuhan laba (DLAB), pertumbuhan Modal (DMOD) dan pertumbuhan penjualan (DPEN).

Tabel 1.

Kualitas Kriteria Model

\begin{tabular}{|l|c|r|r|r|r|r|}
\hline & AVE & Com posite Reliability & R Square & Cronbachs Alpha & Comm unality & Redundancy \\
\hline Kinerja Usaha & 0.591332 & 0.812533 & 0.776371 & 0.655058 & 0.591332 & 0.450285 \\
\hline Perilaku Bisnis & 0.510067 & 0.838506 & & 0.773622 & 0.510067 & \\
\hline Tata Kelola & 0.634104 & 0.838432 & & 0.712132 & 0.634104 & \\
\hline
\end{tabular}

Sumber: data olahan

Tabel 1. dapat disampaikan bahwa nilai loading factor dan nilai composite reliability menyimpulkan bahwa indikator dari masing-masing variabel telah reliable dan valid untuk merefleksikan variabelnya masing-masing. Nilai 
R Square sebesar 0,776 menunjukkan kontribusi pengaruh perilaku bisnis dan tata kelola terhadap kinerja usaha. Artinya semua indikator dan variabel dalam penelitian merupakan model yang layak untuk memprediksi model.

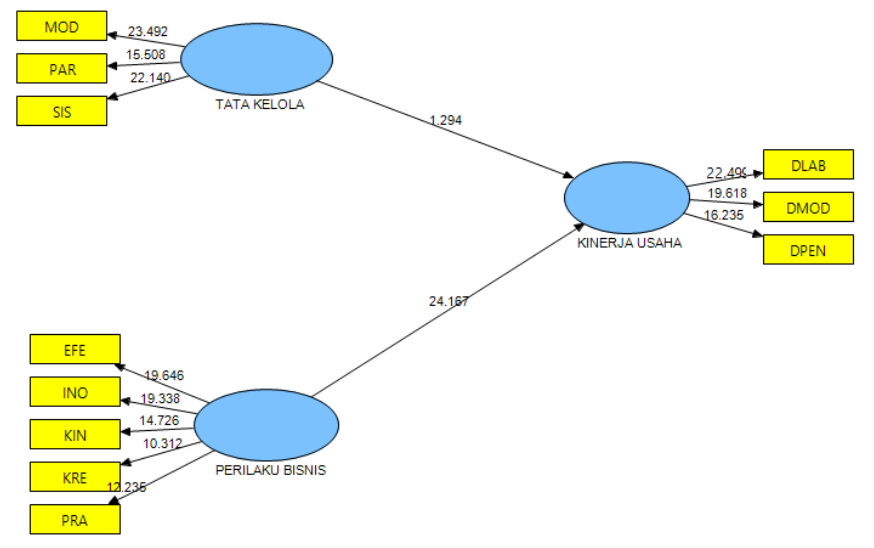

Sumber: data olahan

\section{Gambar 7. \\ Hasil Bootstrapping Model Kedua}

Tabel 2.

Outer Loading

\begin{tabular}{|l|c|c|c|r|r|}
\hline & $\begin{array}{c}\text { Original Sample } \\
(\mathrm{O})\end{array}$ & $\begin{array}{c}\text { Sample Mean } \\
(\mathrm{M})\end{array}$ & $\begin{array}{c}\text { Standard Deviation } \\
(\mathrm{STDEV})\end{array}$ & $\begin{array}{c}\text { Standard Error } \\
(\text { STERR })\end{array}$ & $\begin{array}{c}\text { T Statistics } \\
(\mid \mathrm{O} / \mathrm{STERR})\end{array}$ \\
\hline DLAB <-Kinerja Usaha & 0.810840 & 0.808181 & 0.036038 & 0.036038 & 22.499494 \\
\hline DMOD<-Kinerja Usaha & 0.749882 & 0.749096 & 0.038225 & 0.038225 & 19.617731 \\
\hline DPEN <-Kinerja Usaha & 0.744455 & 0.746110 & 0.045856 & 0.045856 & 16.234757 \\
\hline EFE <-Perilaku Bisnis & 0.772127 & 0.770888 & 0.039303 & 0.039303 & 19.645578 \\
\hline INO <- Perilaku Bisnis & 0.723475 & 0.723695 & 0.037412 & 0.037412 & 19.338074 \\
\hline KIN <-Perilaku Bisnis & 0.718478 & 0.716613 & 0.048789 & 0.048789 & 14.726111 \\
\hline KRE <- Perilaku Bisnis & 0.667210 & 0.666362 & 0.064702 & 0.064702 & 10.312063 \\
\hline MOD <- Tata Kelola & 0.843960 & 0.841001 & 0.035926 & 0.035926 & 23.491697 \\
\hline PAR <- Tata Kelola & 0.775648 & 0.772811 & 0.050017 & 0.050017 & 15.507735 \\
\hline PRA <- Perilaku Bisnis & 0.685099 & 0.678857 & 0.055995 & 0.055995 & 12.234933 \\
\hline SIS <- Tata Kelola & 0.767081 & 0.767450 & 0.034647 & 0.034647 & 22.139982 \\
\hline
\end{tabular}

Sumber: data olahan

Tabel 2. maka dapat disimpulkan bahwa dari variabel perilaku bisnis, indikator yang paling dominan adalah Efisiensi dengan nilai sebesar 19.646. Hal ini menandakan bahwa konsumen yang datang ke food truck mengharapkan layanan dan proses yang efisien. Konsumen tidak perlu duduk menunggu terlalu lama dalam membeli. Sementara itu, indikator dengan nilai paling kecil berasal dari kreativitas dengan nilai sebesar 12.236. Hal ini berarti meskipun kreativitas dibutuhkan, namun dalam penerapannya efisiensi layanan lebih diutamakan dibandingkan kreativitas. Food booth menuntut kecepatan layanan dalam penyajian makanan, sehingga ruang untuk menyajikan kreativitasnya tidak terlalu besar. Selain itu, Tabel 2 juga dapat disimpulkan bahwa dalam variabel kinerja usaha, indikator yang paling dominan adalah indikator pertumbuhan laba. Hal ini mengindikasikan bahwa semakin efisien layanan yang diberikan oleh pihak food booth, maka akan menaikkan laba. Ketika layanan yang diberikan efisien, maka kemungkinan konsumen yang datang akan lebih banyak yang berimplikasi pada peningkatan laba. Sementara itu, indikator yang paling tidak dominan (memiliki nilai terkecil) merupakan indikator pertumbuhan penjualan. Hal ini berarti pertumbuhan penjualan akan lebih meningkat apabila dalam variabel perilaku bisnis didukung oleh variabel lain.

Tabel 3.

Total Effect

\begin{tabular}{|l|c|c|c|c|c|}
\hline & $\begin{array}{c}\text { Original Sample } \\
(\mathrm{O})\end{array}$ & $\begin{array}{c}\text { Sample Mean } \\
(\mathrm{M})\end{array}$ & $\begin{array}{c}\text { Standard Deviation } \\
(\mathrm{STDEV})\end{array}$ & $\begin{array}{c}\text { Standard Error } \\
\text { (STERR) }\end{array}$ & $\begin{array}{c}\text { T Statistics } \\
(\text { OO/STERR) }\end{array}$ \\
\hline Perilaku bisnis > Kinerja Usaha & 0.929046 & 0.928941 & 0.038442 & 0.038442 & 24.167232 \\
\hline Tata Kelola -> Kinerja Usaha & -0.075522 & -0.071928 & 0.058355 & 0.058355 & 1.294178 \\
\hline
\end{tabular}

Sumber: data olahan 
Tabel 3. Terlihat bahwa pengaruh perilaku bisnis terhadap kinerja usaha memiliki t statistic 24,17 > 1,96 dan memiliki original sample sebesar 0,93. Hal ini menunjukkan bahwa perilaku bisnis mempunyai pengaruh positif yang signifikan terhadap kinerja usaha. Hal ini berarti semakin tinggi perilaku bisnis yang diproyeksikan oleh efisiensi, inovasi, kekinian, kreativitas dan praktis maka semakin meningkatkan kinerja usaha yang diproyeksikan oleh pertumbuhan modal, pertumbuhan laba dan pertumbuhan penjualan. Dengan demikian, food booth/ container dengan tingkat efisiensi, inovasi, kreativitas yang tinggi dan disertai dengan penjualan produk yang kekinian (up to date) akan meningkatkan modal, laba dan penjualan. Sementara itu, Tabel 5.4 terlihat bahwa pengaruh tata kelola terhadap kinerja usaha memiliki t statistic 1,294 < 1,96 dan memiliki original sample sebesar -0,076. Hal ini menunjukkan bahwa tata kelola yang diproyeksikan oleh modern, partnership dan sistematis tidak memiliki pengaruh terhadap kinerja usaha yang diproyeksikan oleh pertumbuhan modal, pertumbuhan laba dan pertumbuhan penjualan. Hal ini berarti proses penyajian makanan food truck yang modern, bermitra dengan usaha lain serta sistematis tidak mampu menaikkan pertumbuhan modal, pertumbuhan laba dan pertumbuhan penjualan. Oleh karena itu, dapat disimpulkan pada food booth di provinsi Jambi bahwa perilaku bisnis lebih mempengaruhi kinerja usaha dibandingkan dengan tata kelola. Dengan demikian dapat disimpulkan bahwa perilaku bisnis food booth/container di Provinsi Jambi yang direfleksikan oleh efisiensi, inovasi, kekinian, kreativitas dan praktis mempengaruhi kinerja usaha yang direfleksikan oleh pertumbuhan modal, pertumbuhan laba dan pertumbuhan penjualan. Sebaliknya, tata kelola yang direfleksikan oleh modern, partnership dan sistematis tidak mempengaruhi kinerja usaha yang direfleksikan oleh pertumbuhan modal, pertumbuhan laba dan pertumbuhan penjualan

\section{Simpulan}

Berdasarkan metode kualitatif diperoleh variabel dan indikator. Perilaku bisnis terdiri dari 5 (lima) indikator, yaitu: e-money (E-money), kemandirian (MAN), modern (MOD), partnership (PAR), dan sistematis (SIS). Kemudian variabel perilaku bisnis terdiri dari 7 (tujuh) indikator keefektifan (EFE), efisiensi (Efi), Inovatif (INO), Kekinian (KIN), kreativitas (KRE), Praktis (PRA) dan Kesederhanaan (SED). Sementara itu, variabel kinerja usaha terdiri dari 3 (tiga) indikator yaitu pertumbuhan laba (DLAB), pertumbuhan Modal (DMOD) dan pertumbuhan penjualan (DPEN). Berdasarkan metode kuantitatif diperoleh kesimpulan bahwa perilaku bisnis food booth/ container di Provinsi Jambi yang direfleksikan oleh efisiensi, inovasi, kekinian, kreativitas dan praktis mempengaruhi kinerja usaha yang direfleksikan oleh pertumbuhan modal, pertumbuhan laba dan pertumbuhan penjualan. Sebaliknya, tata kelola yang direfleksikan oleh modern, partnership dan sistematis tidak mempengaruhi kinerja usaha yang direfleksikan oleh pertumbuhan modal, pertumbuhan laba dan pertumbuhan penjualan.

\section{Daftar Pustaka}

Abrahale, K., dan S. Sousa. 2018. Street food research worldwide : a scoping review. Journal of Human Nutrition and Dietetics 32:152-74. doi: 10.1111/jhn.12604.

Alfiero, Simona, Agata Lo Giudice, dan Alessandro Bonadonna. 2017. Street food and innovation: the food truck phenomenon. British Food Journal. doi: https://doi.org/10.1108/BFJ-03-2017-0179.

Alves da Silva, Sueli, Ryzia de Cassia Vieira Cardoso, José Ângelo Wenceslau Góes, Jessica Nascimento Santos, Flávia Pascoal Ramos, Rubia Bispo de Jesus, Renata Sabá do Vale, dan Priscila Santos Teles da Silva. 2014. Street food on the coast of Salvador, Bahia, Brazil: A study from the socioeconomic and food safety perspectives. Food Control 40(1):78-84. doi: 10.1016/j.foodcont.2013.11.022.

Chaisena, Komkrit, Nongnapas Thiengkamol, dan Chatchai Thiengkamol. 2013. Environmental Conservation Promotion for Food Stand Entrepreneur. European Journal of Scientific Research 104(4):603-13.

Chavez, Jose B. Rosales, Meg Bruening, Punam Ohri-vachaspati, dan Rebecca E. Lee. 2021. Street Food Stand Availability, Density, and Distribution Across Income Levels in Mexico City. International Journal of Environmental Research and Public Health 18:1-17. doi: https://doi.org/10.3390/ ijerph18083953.

Danielsson, Filip. 2020. Indikators for sustainable food sales A case study developing a climate indikator for Swedish food. Chalmers University of Technology.

Gupta, Vikas, Kavita Khanna, dan Raj Kumar Gupta. 2018. A study on the street food dimensions and its effects on consumer attitude and behavioural intentions. Tourism Review. doi: 10.1108/TR-03-2018-0033.

Morano, Rogerio Scabim, Alcides Barrichello, Rafael Ricardo Jacomossi, dan Jorge Ramon D'Acosta-Rivera. 2018. Street food: factors influencing perception of product quality. RAUSP Management Journal 53(4):535-54. doi: 10.1108/RAUSP-06-2018-0032.

Privitera, Donatella, dan Francesco Saverio Nesci. 2015. Globalization vs. Local. The Role of Street Food in the Urban Food System. Procedia Economics and Finance 22(November 2014):716-22. doi: 10.1016/s22125671(15)00292-0. 